\title{
MUSHROOM FARMING IN IRAN: A CASE STUDY OF TEN IRANIAN MUSHROOM COMPANIES
}

\author{
Saeed Nostratabadi, Szergej Vinogradov, Bernadett Almádi \\ Szent István University
}

\begin{abstract}
In terms of mushroom production, Iran is one of the leading countries in the world as mushrooms productions play an utmost important role in non-oil export in the country. Therefore, this study aimed to evaluate the financial aspect of mushroom cultivation in Iran. To this end, the current study sought to find the operational costs and potential revenue of mushroom cultivation in Iran. This qualitative experimental study, using in-depth semistructured interviews with mushroom producers, examines their current situation in Iran. The findings show that mainly two types of mushrooms are produced in Iran, namely Agaricus bisporus (champions) and oyster mushrooms. It is also revealed that although the number of oyster mushroom production units is increasing every year, the profitability of Agaricus bisporus in Iran is higher. Despite the industry's profitability in Iran, mushroom growers in Iran are dissatisfied with their business and cite a number of reasons, including low profitability, low demand, seasonal demand, limited transportation, and economic instability.

KEY WORDS: mushroom growing; production cost structure; profit percentage; barriers of mushroom farming.
\end{abstract}

\section{Introduction}

Many mushrooms are widely known as a food source, as condiments for enriching the flavor of dishes, as well as supplements to help maintain good health. These properties have increased the demand for more edible mushrooms. Currently, mushrooms are grown in more than a hundred countries around the world (Chang \& Miles 2004). Mushroom production and consumption are on the rise worldwide. The development of the AsiaPacific region is significant, accounting for $82.54 \%$ of the amount of mushrooms grown. The annual turnover of the international mushroom market was $\$ 35$ billion in 2015, approaching $\$ 50$ billion by 2019 , and further strong growth is expected in the coming years as well (Markets and Markets 2019).

Iran is one of the top ten countries in producing mushrooms in the world. Figure 1 shows that Iran's mushroom production peaked in 2014, a drastic decrease was observed in 2015 and 2016, growth in 2017 and 2018 could not compensate for this decline, the volume of mushroom production in 2018 does not reach the 2011 level.

During 2014-2017 Iranian Economic was imposed sanctions that affected the trade. Buying raw materials from the outside of the country and exporting products were affected, as many producers, who mainly relied on the foreign customers, lost their market. It can be a possible reason for reduction the production during these three years.

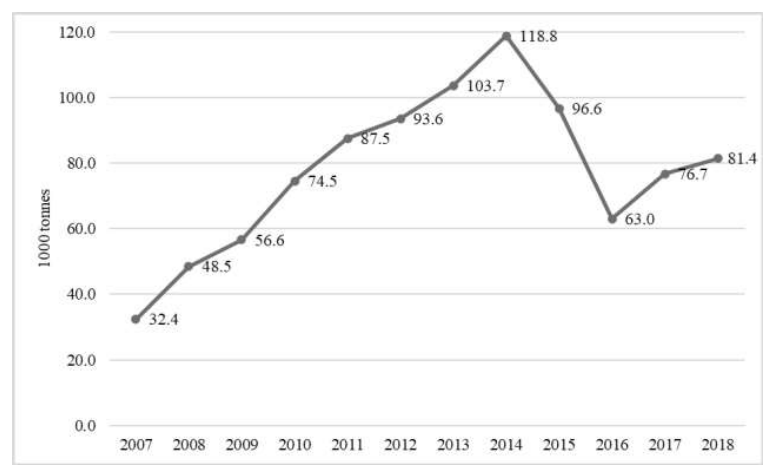

Fig. 1. The annual volume of cultivated mushrooms in Iran, 2007 - 2018, tonnes

Source: the authors' edition based on the data of FAO 2020

To the world mushroom production and consumption have increased significantly in recent years. This growth is due to the nutritional and health benefits of mushrooms. The importance of mushroom cultivation for different areas is summarized in Table 1. 
Table 1. The importance of mushroom growing

\begin{tabular}{|l|l|l|}
\hline Field & Role & Source \\
\hline $\begin{array}{l}\text { Environment } \\
\text { protection and waste } \\
\text { management }\end{array}$ & $\begin{array}{l}\text { Production based on agricultural, } \\
\text { forestry and food processing } \\
\text { byproducts and waste products }\end{array}$ & $\begin{array}{l}\text { Chen 2005, Gyenge et al. 2016, Kozma et al. } \\
\text { 2016, Carrasco-Cabrera et al. 2019, Figlas et al. } \\
2016\end{array}$ \\
\hline $\begin{array}{l}\text { Environment } \\
\text { protection }\end{array}$ & $\begin{array}{l}\text { Mushrooms absorb toxic } \\
\text { substances from the soil. }\end{array}$ & $\begin{array}{l}\text { Alemu 2015, Chang \& Miles 2004, Gunday et al. } \\
\text { 2012 }\end{array}$ \\
\hline Food production & $\begin{array}{l}\text { Mushrooms are healthful and safe } \\
\text { sources of nutrition (they have low } \\
\text { carbohydrate content and are rich in } \\
\text { proteins and fibers). }\end{array}$ & $\begin{array}{l}\text { Raman et al. 2018, Smith 1993, Vetter 2003, } \\
\text { Beyer 2017 }\end{array}$ \\
\hline Mycotherapy & $\begin{array}{l}\text { Mushrooms have beneficial health } \\
\text { effects and are successfully used in } \\
\text { supporting the treatment of various } \\
\text { types of cancer and other serious } \\
\text { illnesses. }\end{array}$ & $\begin{array}{l}\text { Zmitrovich et al. 2019, Zhang et al. 2018, Zhang } \\
\text { et al. 2019, Györfi 2010, Hassan et al. 2010, } \\
\text { Daba et al. 2008, Kumar 2015, Maning et al. 2000, }\end{array}$ \\
\hline Poverty reduction & $\begin{array}{l}\text { Mushroom production is labor } \\
\text { intensive and creates a high number } \\
\text { of jobs. }\end{array}$ & $\begin{array}{l}\text { Chen 2005, Ferchak \& Croucher 2001, Imtiaj \& } \\
\text { Rahman 2008, Barmon et al. 2012, Lelley 1988, } \\
\text { Pegler 2002 }\end{array}$ \\
\hline
\end{tabular}

Source: the authors' own edition

The market share of mushroom production and trade reached 35 billion dollars globally in 2015, and is expected to reach 60 billion dollars by 2021, which adds up to approximately $9.2 \%$ increase per year (Markets and markets 2019, Fresh Plaza 2016).

Currently, mushrooms are produced in over 100 countries (Suman \& Sharma 2007). According to Sánchez (2004), mushroom production was the fastest developing area of the horticultural sector up until the end of the $20^{\text {th }}$ century.

According to FAO (2018), twelve species dominate mushroom production and the world market:

- Button mushrooms (Agaricus bisporus and Agaricus bitorquis),

- Shiitake (Lentinula edodes),

- Oyster mushrooms and abalone mushrooms (Pleurotus spp.),

- Golden needle or enoki mushrooms (Flammulina velutipes),

- Wood ear mushrooms (Auricularia spp.) especially Jew's ear mushrooms (Auricularia auricula-judae),

- Shaggy ink cap mushrooms (Coprinus comatus),

- Lion's mane mushroom (Hericium erinaceus),

- Straw mushroom (Volvariella spp.),

- Hen-of-the-woods or maitake mushroom (Grifola frondosa),

- Nameko (Pholiota nameko),

- Reishi mushroom (Ganoderma lucidum).

From this list, only the first six varieties are produced in significant quantities (Raut 2019).

According to FAO, worldwide mushroom production increased by $7.6 \%$ from 2006 until 2016, with the most significant expansion in China, the USA, the Netherlands, India and Vietnam (2018).

Iran has supportive policies for small businesses, which has led to increased investment in mushrooms production as well, which has subsequently boosted the industry and created many job opportunities. Increased production and export of mushrooms products have played a significant role in Iran's non-oil exports. As many as 30 tons of edible mushrooms are exported to neighboring countries of Iran daily (Fig. 2.).

Edible mushrooms cultivation activity in Iran is mainly in the form of two types of oyster mushrooms and Agaricus bisporus (champions). In 2017, there were 1613 edible mushrooms farms throughout Iran, of which 1587 farms were Agaricus bisporus, 19 farms were oyster and 7 farms were cultivated in both types of mushrooms.

The number of edible mushrooms farms increased by $56 \%$ from 2012 to 2017 (Statistical Center of Iran, 2017). 7424 people worked in the mushrooms farms in 2017, of which $30 \%$ were women.

Compared with 2012, the number of people engaging in mushrooms farms increased by $29 \%$, which shows this production has created many job opportunities so far. Having a close look at mushrooms production reveals that 62957 tons of edible mushrooms produced in 2017, of which 627231 tons were Agaricus bisporus and 234 tons were oyster mushrooms, while the production of oyster mushrooms has increased by $99 \%$ compared to 2012 (Statistical Center of Iran, 2017).

One of the ways the Iranian government has considered reducing unemployment is to provide supportive programs for entrepreneurship.

Mushrooms production in Iran is one of the practical examples that has been able to create permanent employment for individuals, which creates one job for every 5 tons of Agaricus bisporus compost per month.

In general, mushrooms growers in Iran have three incentives for mushrooms production:

1) there is a demand for mushrooms and mushroom products in Iran;

2) mushrooms cultivation is early-yielding; and

3) there is no agricultural land or irrigation that is important because most of the regions in Iran suffer from drought and favorable land for agriculture.

Although Iran is one of the largest mushrooms producers in the world, there is limited information in the literature regarding the launch of a mushrooms production in Iran. 
To this end, the present study aims to bridge this gap in the literature and provide a complete picture of the processes and economic analysis of launching such a business in Iran.

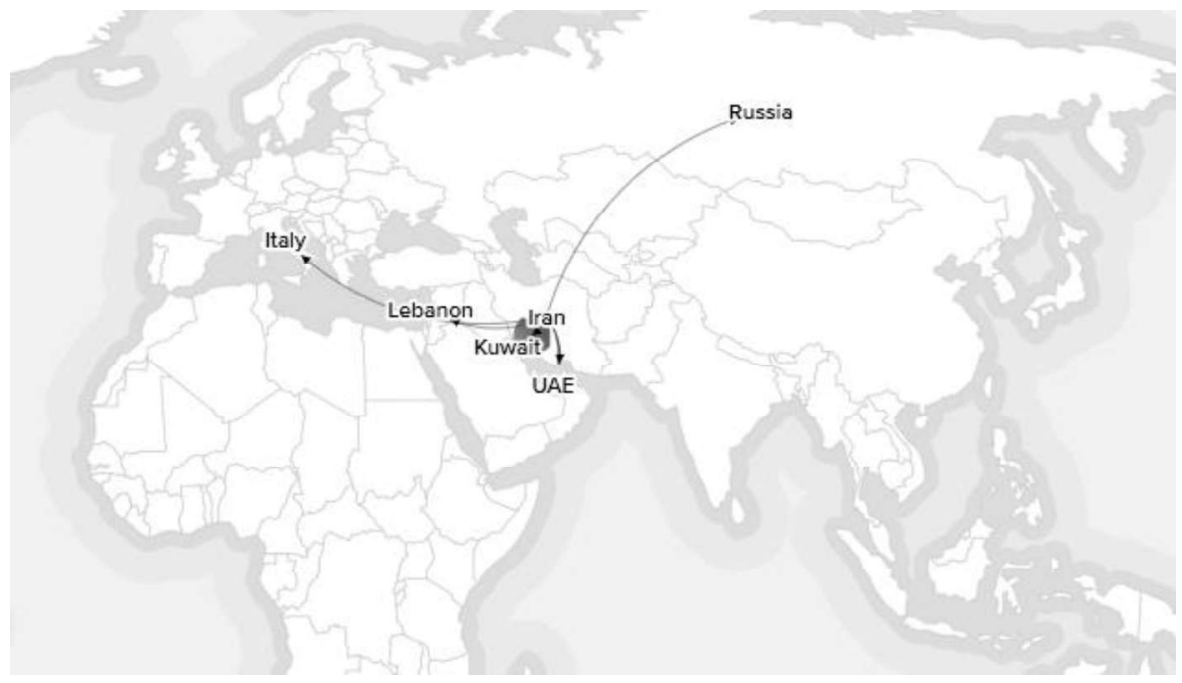

Fig. 2. Import and export by Iran in 2018

Source: the authors' edition based on the data of FAO

\section{Methodology}

This study is a descriptive research project using qualitative methodology to address the objectives. To study the status of mushroom cultivation and the financial aspect of running a mushrooms company in Iran, 10 managers of mushrooms production companies in Iran were interviewed. Semi-structured interviews were run among these managers for data collection.

Contact addresses of the mushrooms companies were collected from the website of Iranian ministry of agriculture. Fifty companies were selected randomly and contacted via email by one of the study's authors. Only 10 of the companies agreed to participating in this research.

Due to privacy reasons, this study refrains from mentioning the brand of the interviewed companies.

\section{Result and discussion}

Although the number of Agaricus bisporus production units is far greater than the number of oyster mushroom ones, the growth rate of oyster mushroom growing units is considerable and it is remarkably higher than Agaricus bisporus units in Iran. Figure 1 shows the appearance of Agaricus bisporus and oyster mushroom. In this figure, the image on the left is the Agaricus bisporus, and the image on the right is the oyster mushroom. Seven of out of ten companies participated in this study produced Agaricus bisporus and the remaining three produced oyster mushrooms. It is worth mentioning that all the interviewees were company executives.

A demographic analysis disclosed that all the managers were older than 30 years of age, and all of them were male. It is also revealed that all the managers had a bachelor's degree. Four mushrooms production managers had a degree in either agriculture or food science, and the rest had a different degree (Table 2), such as mechanical engineering, business management, economics, and metallurgy.

Table 2. Demographic characteristics of the interviewees in this study

\begin{tabular}{|l|c|c|c|}
\hline \multicolumn{1}{|c|}{ Product type } & Age & Degree & Traning Programs \\
\hline Agaricus bisporus & 32 & Bachelor's in Mechanical Engineering & Once \\
\hline Agaricus bisporus & 55 & Bachelor's in Agricultural Engineering & Never \\
\hline Agaricus bisporus & 41 & Bachelor's in Food Science & Never \\
\hline Agaricus bisporus & 32 & Bachelor in Agricultural Engineering & Never \\
\hline Agaricus bisporus & 44 & Bachelor's in Business Management & Once \\
\hline Agaricus bisporus & 52 & Bachelor's in Economics & Once \\
\hline Agaricus bisporus & 55 & Bachelor's in Metallurgy & Once \\
\hline Oyster mushroom & 45 & Bachelor's in Agricultural Engineering & Never \\
\hline Oyster mushroom & 52 & Bachelor's in Economics & Once \\
\hline Oyster mushroom & 54 & Bachelor's in Business Management & Once \\
\hline
\end{tabular}

Source: the authors' own construction based on own survey data 
Table 2 shows that all the managers had a degree other than agricultural engineering and food science participated in a training course.

All of them only attended such courses once in their early years as one of the interviewees mentioned that "... I only attended a training program just 15 years ago when I decided to start this company, and when I got into it I learned from practice that I didn't feel the need to attend any related courses...".

Three of the companies produced Agaricus bisporus are among the largest mushrooms producers in Iran, exporting their products to Iraq in addition to selling their products in different provinces of Iran. In addition to mushrooms, these three companies produced blanch mushrooms for other food processing companies.

It is also turned out that in addition to the initial investment by the founders, all producers used bank loans at the beginning of their business.

Apart from the website and the profiles of corporations on social media platforms, most mushrooms production companies in Iran have no other marketing channel, and only one company mentioned that "... We regularly have ads on one small business advertising website every six months ..." .

The executives point out two major reasons why they do not need advertising:
1) All their production capacity is purchased by wholesalers and

2) The brand is already established and does not need advertising.

To produce mushrooms, all the producers purchased compost, and none of them made compost themselves. Studying the costs of mushrooms producers illustrates that the cost of buying compost is their main cost

Fig. 3. shows that compost costs accounted for between $43 \%$ and $74 \%$ of the total cost of producing one kilogram of mushroom. In the case of champignons, the cost of the peat is included in the compost cost. The cost of compost for growing oyster mushrooms is higher compared to champignons because it is produced according to a special recipe (various from species to species) under laboratory conditions. Just a few composting plants produce compost for growing oyster mushrooms.

The first seven companies are Agaricus bisporus producers and the other three are oyster mushroom producers. It indicates that the share of compost costs in Agaricus bisporus production is lower than the share of compost costs in oyster mushrooms production.

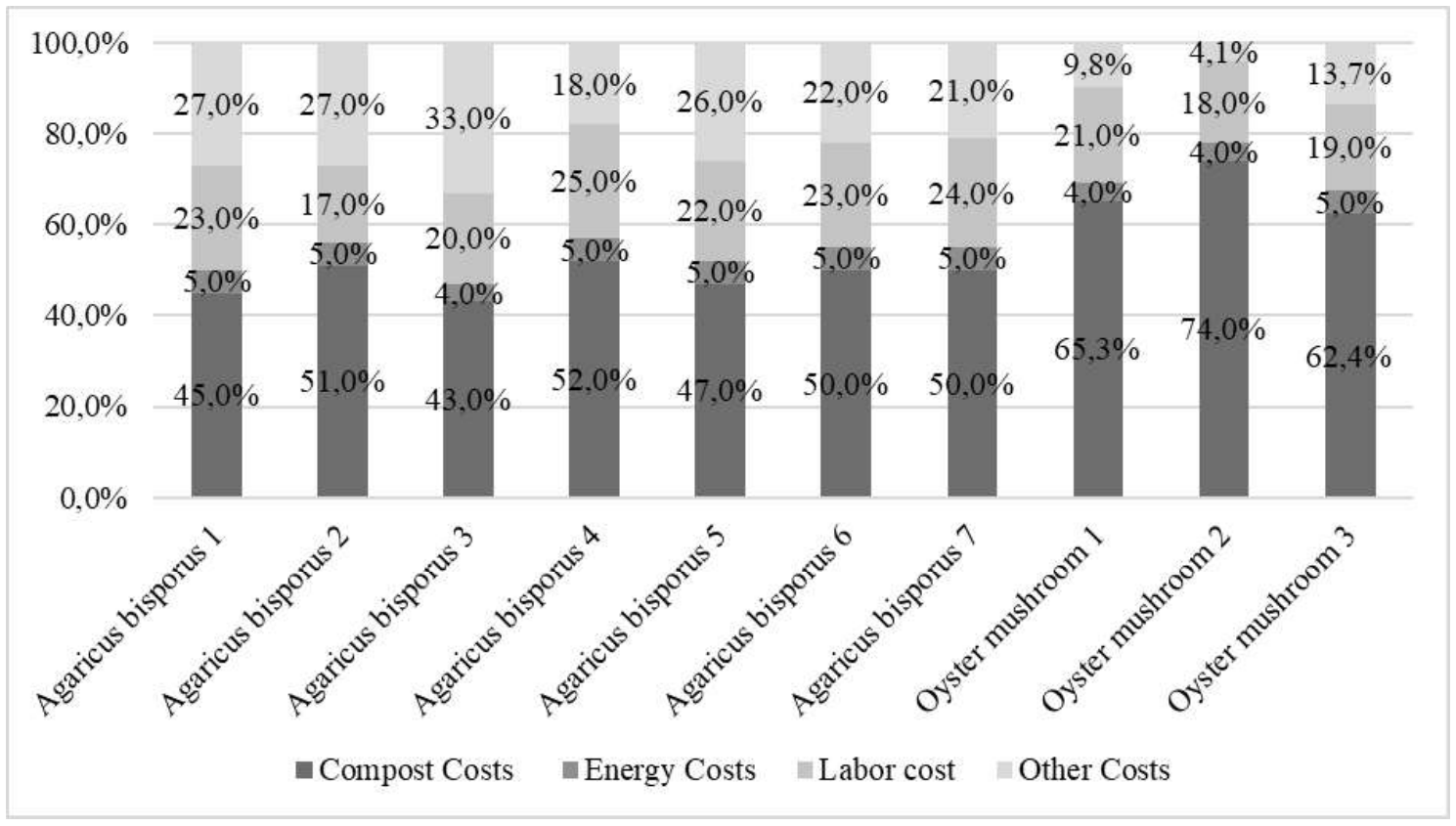

Fig. 3. The share of energy, compost, and packaging costs in the production cost of mushroom cultivation in Iran

Source: the authors' own calculation based on own survey data

The proportion of labor costs is $17-25 \%$ of total production costs. All the producers sell $80 \%$ of their products in bulk and $20 \%$ of them in packaged form. The packaging increases labor costs.
Since mushrooms production in Iran is considered an agricultural activity, not an industrial activity, energy costs include government subsidies. 
As a result, energy costs in mushroom production have been very low, accounting for a smaller share of total production costs.

Other costs include the cost of modern mushroom growing houses, equipment, and machinery (eg forklifts), depreciation, material costs (plant protection costs for mushrooms), disinfection costs for growing equipment, maintenance costs, and transportation costs.
In addition, agricultural activities in Iran are tax exempt therefore the businesses do not pay tax. On the other hand, buyers, who are mainly wholesalers, bear the cost of shipping. This means that mushroom producers do not bear any transportation costs.

In order to clarify how economically viable mushrooms production in Iran is, the profit percentage was calculated using Equation 1 for each of these producers and the results are shown in Figure 4.

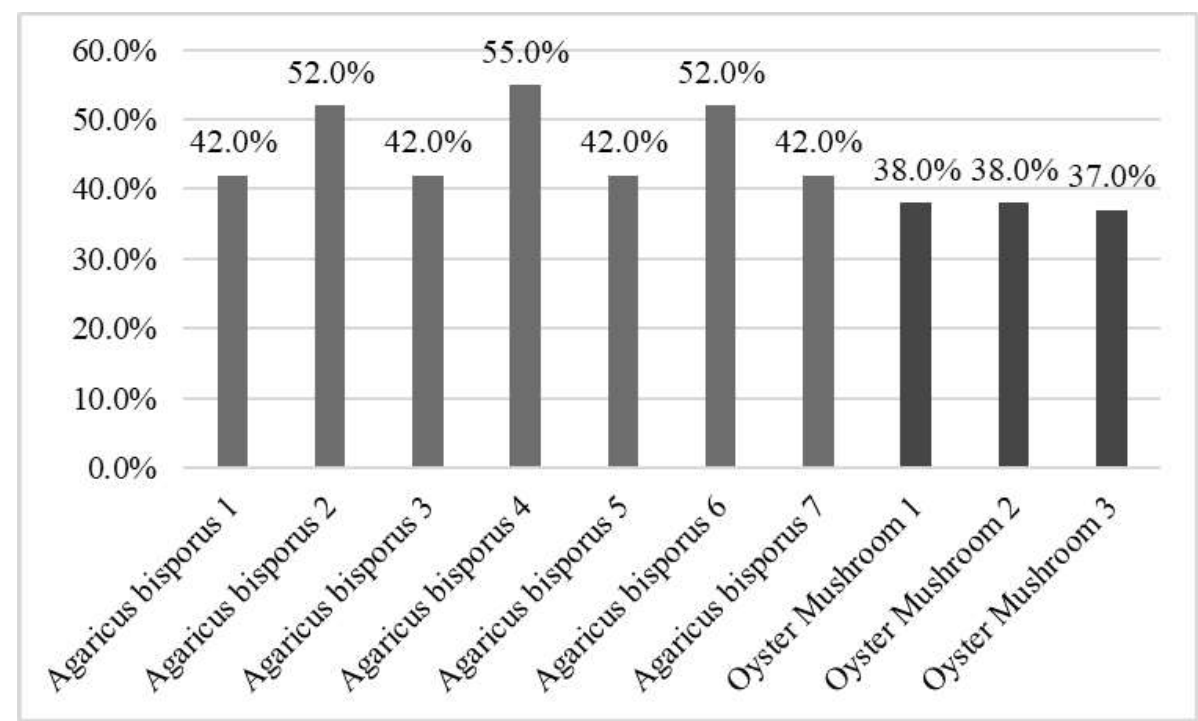

Fig. 4. Profit percentage for Iranian mushroom producers investigated in this study

Source: the authors' own calculation based on own survey data

Since the value of Iran's currency, which is IRR, is remarkably lower that USD and reporting the profits and the prices in IRR shows high figures.

When these figures are converted into dollars or euros, they look very small. Therefore, to avoid any misinterpretation this study use profit percentage. As it is presented in Equation 1, to calculate the profit percentage, the difference between the selling price and the production costs of one kilogram of mushrooms was divided by the selling price, which indicates what percentage of the selling price of one kilogram of mushrooms is the producer's profit.

$$
\begin{gathered}
\text { Profit } \\
\text { percentage }
\end{gathered}=\frac{\text { sale price }- \text { production cost }}{\text { sale price }} \cdot 100 \%
$$

Figure 4. shows that the profit percentage for Agaricus bisporus producers is between $42 \%$ to $55 \%$. This means that $42 \%$ of the sales of Agaricus bisporus producer 1, for example, is profit.

All respondents believe that marketing activities aimed at mushroom growing in Iran are not typical.

The executive managers were asked to express their satisfaction with their business by choosing a number between one and six, where one represents the lowest level of satisfaction and six indicates the highest level of satisfaction.

Table 3 shows that most managers are dissatisfied with their business conditions, and only two of them have given four out of six to their satisfaction levels.
Four out of ten managers cited low profitability as the main reason for their dissatisfaction.

For example, one manager argued that "... the profit we received from this business was one-tenth of the expected profit ...", or another manager pointed out that "... the implicit cost of this industry is so high that I could have made more profit with a similar capital in another industry ..." and another executive said that" ... if I could go back to fifteen years ago, I would never have gone into this business and chosen a different path....".

Low demand and seasonal demand are other reasons why some managers have expressed dissatisfaction with their business. "...demand falls sharply in certain months, such as Ramadan..." on the executives said. "...despite growing demand in recent years, the market size is still small..." another executive said.

Two producers have cited the lack of proper transportation to ship their products to other cities as one of the most serious limitations to their business development.

Finally, one of the managers considers the instability of the economy in Iran as the main obstacle to progress and success in its business. "... the instability in the economy and inflation has caused the price of seeds and composts to fluctuate, and we are seeing an increase in their prices every day, while the prices of our products are not rising at the same rate ... this increase in prices has a negative effect on demand..." he said. 
Table 3. Managers' satisfaction with their business and barriers of mushroom farming

\begin{tabular}{cll}
\hline Product type & Satisfaction & \multicolumn{1}{c}{$\begin{array}{c}\text { Barriers of mushroom } \\
\text { farming }\end{array}$} \\
\hline Agaricus bisporus 1 & 1 & Low Profitability \\
\hline Agaricus bisporus 2 & 3 & Seasonal Demands \\
\hline Agaricus bisporus 3 & 2 & Low Profitability \\
\hline Agaricus bisporus 4 & 4 & Limited transportation \\
\hline Agaricus bisporus 5 & 1 & Seasonal Demand \\
\hline Agaricus bisporus 6 & 4 & Economic instability \\
\hline Agaricus bisporus 7 & 2 & Low Profitability \\
\hline Oyster mushroom 1 & 2 & Low Profitability \\
\hline Oyster mushroom 2 & 1 & Low Demand \\
\hline Oyster mushroom 3 & 3 & Limited transportation \\
\hline
\end{tabular}

Source: the authors' own calculation based on own survey data

\section{Conclusion}

Mushrooms play an important role in food security and providing healthy food to consumers. Iranian mushrooms producers are among the top ten mushrooms producers in the world.

In this study, the economic status of running a mushrooms company in Iran was investigated. Findings of 10 semi-structured interviews with the executives of mushrooms producers in Iran revealed that there are mainly two types of mushrooms produced in Iran, namely Agaricus bisporus and oyster mushrooms.

It was also revealed that although the number of oyster mushroom production units is increasing every year, the profitability of Agaricus bisporus in Iran is higher. Despite the industry's profitability in Iran, mushroom growers in Iran are dissatisfied with their business and cite a number of barriers of mushroom farming, including low profitability, low demand, seasonal demand, limited transportation, and economic instability.

In the cost structure of mushroom growing in Iran, the largest share (from 43 to $74 \%$ ) is represented by the cost of compost, the labor cost is $17-25 \%$, the share of energy costs is the lowest, around $4-5 \%$. Mostly the cultivated mushroom species determine the production cost structure.

The authors consider it necessary to develop training opportunities for mushroom growers aimed at getting to know other species and bringing them into cultivation. In parallel with the training of growers, it is important to create a national campaign that informs consumers about mushroom species and their role in human nutrition.

The contributions of the study provide valuable insights of the cost-benefits of this sector for entrepreneurs and practitioners interested in investing in this sector in Iran. It is necessary to continue the international exchange of experience, which focuses on technological developments, thus contributing to more cost-effective mushroom production.

\section{Acknowledgement}

The current research project was supported by the program for New National Excellence, Ministry of Innovation and Technology, grant number ÚNKP-19-3III.SZIE-8."

\section{References}

Alemu, F. (2015). Cultivation of Shiitake Mushroom (Lentinus edodes) on Coffee Husk at Dilla University Ethiopia. Journal of Food and Nutrition Sciences, 3(2), 63-70.

Barmon, B.K., Imrana, S., Parvez, K.A., Mamun, A. (2012). Economics of Mushroom (Agaricus bisporus) Production in a Selected Upazila of Bangladesh, Department of Economics, East West University, Dhaka, Bangladesh, A Scientific Journal of Krishi Foundation index journal The Agriculturists, v. 10, n. 2, 77-89.

Beyer, D.M. (2017). Six steps to mushroom farming. Penn State Extension. Retrieved from https://extension.psu.edu/sixsteps-to-mushroom-farming. Accessed 21 April 2017

Carrasco-Cabrera, C., Bell, T.L, Kertesz, M.A. (2019). Caffeine metabolism during cultivation of oyster mushroom (Pleurotus ostreatus) with spent coffee grounds, Applied microbiology and biotechnology, Volume: 103 Issue: 14, 5831-5841

Chang, S.T., Miles, P.G. (2004). Mushrooms Cultivation, Nutritional Value, Medicinal Effect, and Environmental Impact, CRC Press

Chen, W.A. (2005). What is shiitake, In: Shiitake Cultivation, Mushroom Growers Handbook 2., MushWorld 24. p.

Daba, A.S., Kabeil, S., Botros, W.A., El-Saadani, M. (2008). Production of mushroom (Pleurotus ostreatus) in Egypt as a source of nutritional and medicinal food. In: World Journal of Agricultural Sciences, 4: 630-634.

Ferchak, J.D., Croucher, J. (2001). Prospects and Problems in Commercialization of Small-Scale Mushroom Production in South and Southeast Asia. Appropriate Technology International, Washington DC, USA, 321-329.

Figlas, N.D., Matute, R.G., Curvetto, N.R. (2016). Sunflower Seed Hull: Its Value as a Broad Mushroom Substrate. Journal of Food Processing and Preservation, 1(1): 1002

Gunday, M.G.A., Biswas, W., Solah, V.A., James, A.P. (2012). Evaluating the global warming potential of the fresh produce supply chain for strawberries, romaine/cos lettuces (Lactuca sativa), and button mushrooms (Agaricus bisporus) 
in Western Australia using life cycle assessment (LCA). Journal of Cleaner Production, 28, 81-87

Gyenge, B., Kozma, T., Almádi, B., Szarvas, J., Villás, G., Urvölgyi, M. (2016). Technology innovation in sustainable growing and distribution of king oyster mushroom, Hungarian Agricultural Engineering: 29, 5-10.

Győrfi, J. (2010). Mushrooms as functional foods. Int. Journal of Horticultural Sci. 16(5), 7-12.

Hassan, F.R.H., Ghada, M., Medany S.D., Hussein, A. (2010). Cultivation of the King Oyster Mushroom (Plerrotus eryngii) in Egypt. Australian Journal of Basic and Applied Sciences, 4(1): 99-105

Imtiaj, A., Rahman, S.A. (2008). Economic viability of mushrooms cultivation to poverty reduction in Bangladesh. Tropical and Subtropical Agroecosystems, 8, 93 - 99

Kozma, T., Gyenge, B., Almádi, B. (2016). Supply chain participants in the mushroom sector and their role in the added value creatio $\mathrm{n}$ in sustainable way based on a hungarian case study. Vadyba: Journal of Management 28(1), 119-125.

Kumar, K. (2015). Role of edible mushrooms as functional foods-A review South Asian. Journal of Food Technology and Environment, 1(3\&4), $211-218$.

Lelley, J. (1988). Growing Edible Mushrooms Still a Generally Neglected Opportunity. Gate 4, 30-34 pp.

Maning, S.B., Tina, E., Flecher, C. (2000). Medicinal mushrooms: Food for Thought. Mushroom News, 2, 20-23.

Mizumo, M. (2008). Immunomodulatory Activites of B- glukan in mushroom. In: Shibamoto, T., Kanazawa, K., Shahidi, F., Ho, C.T.: Funcional food and health, American Chemical Society

Pandiarajan, G., Govindaraj, R., Mareeswaran J. - Makesh Kumar B. (2012): Antibacterial activity and heavy metal accumulation of edible oyster mushroom (Pleurotus SAJOR-CAJU) grown on two substrates. International Journal of Pharmacy and Pharmaceutical Sciences Vol 4, Issue 2

Pegler, D.N. (2002). Useful fungi of the world: The "Poor man's truffles of Arabia" and "Manna of the Israelites". Myocologist, 16, 8-9.

Raman, J., Lee, S.K., Im, J.H., Oh, M.J., Oh, Y.L., Jang, K.Y. (2018). Current prospects of mushroom production and industrial growth in India. Journal of Mushrooms 16(4), 239-249.

Sánchez, C. (2004). Modern aspects of mushroom culture technology. Appl. Microbiol. Biotechnol, 64, 756-762.

Smith, J.F. (1993). The mushroom industry. In: Jones D.G. (eds), Exploitation of Microorganisms, 249-271 Springer, Dordrecht

Statistical Center of Iran (2017). Census results from Iranian edible mushroom growing units. [Retirive Jan 2020]. https://www.amar.org.ir/Portals/0/News/1396/gharchs96.pdf

Suman B.C., Sharma V.P. (2007). Mushrooms Cultivation in India, pp. 18-22. Daya Publishing House, Delhi

Zhang, Y., Zhang, M., Jiang, Y., Li, X., He, Y., Zeng, P., Guo, Z., Chang, Y., Luo, H., Liu, Y., Hao C., Wang H., Zhang G., and Zhang L. (2018). Lentinan as an immunotherapeutic for treating lung cancer: a review of 12 years clinical studies in China. Journal of Cancer Research and Clinical Oncology 144(11), 2177-2186.

Zmitrovich, I.V., Belova, N.V., Balandaykin, M.E., Bondartseva, M.A., Wasser, S.P. (2019). Cancer without Pharmacological Illusions and a Niche for Mycotherapy (Review). International Journal of Medicinal Mushrooms, Volume 21, 2019 Issue 2, 105-119.

Saeed Nostratabadi, $\mathrm{PhD}$ candidate in Doctoral School of Management and Business Administration in Szent István University (Hungary). Field of scientific research: human resource management, business model innovation, and marketing. E-mail: saeed.nosratabadi@gmail.com

Sergey A. Vinogradov, PhD (in business and management), Associate Professor in Szent István University (Hungary), Faculty of Economic and Social Sciences, Institute of Economics and Methodology. Head of the Department of Methodology. Current research interests: socio-economic statistics, actual problems of sustainable development in EU countries. E-mail: vinogradov.szergej@szie.hu

Almadi Bernadett, assistant lecture and $\mathrm{PhD}$ candidate in Szent István University (Hungary), Faculty of Economic and Social Sciences. Field of scientific research: mushroom growing and economic issues. E-mail: bernadett.almadi@gmail.com 